\title{
EFEKTIVITAS PEMUPUKAN TERHADAP PERTUMBUHAN TERUBUSAN KILEMO (Litsea cubeba L. Persoon) YANG DIPANGKAS
}

\author{
Fertilizer Effectiveness on Coppicesgrowth of Pruned Kilemo \\ (Litsea cubeba L. Persoon) \\ Enny Widyati \\ ${ }^{1)}$ Pusat Penelitian dan Pengembangan Peningkatan Produktivitas Hutan \\ Jl. Gunung Batu No. 5 Bogor 16118 \\ Telp. 0251-8631238 \\ Fax. 0251-7520005 \\ E-mail: enny_widyati@yahoo.com
}

Naskah masuk : 15 Januari 2014; Naskah diterima : 20 Maret 2015

\begin{abstract}
Kilemo (Litsea cubeba L. Persoon) is one of aromatic-oil-producer plants. The,demand of that commodity supplied is still from natural forest by cutting kilemo trees to collect its bark. In consequence, population of kilemo leads to extinct, hence cultivation is crutial to conserve this species. Optimizing shoot productivity can be done by pruning and fertilizing. This study aimed to observe the effectiveness of fertilizer trials on shoot productivity of pruned kilemo. Granulated organic fertilizer produced by factory, NPK (15:15:15), leaf fertilizer contained micronutrients, and non fertilizer, as a control, were applied onto kilemo rhizosphere a month after pruning. Treatments were arranged in randomized-completed design with 15 trees for its units in 3 replications. Numbers, length, productivity of new shoots were calculated to observe the response of treatments on the days of 15, 30, 60, 90 and 120 after pruning. Result showed that organic ferlizer was subjected to be the most effective in increasing soil $N, P, K$ availability hence improving coppice number, length and productivity of kilemo by 116\%, 99\% and 475\%, respectively compared to the control.
\end{abstract}

Keywords: Kilemo, pruning,organicfertilizer, new shoot

\begin{abstract}
ABSTRAK
Kilemo merupakan salah satu tanaman penghasil minyak atsiri. Bagian tanaman yang dapat diekstrak minyaknya adalah daun dan kulit kayunya. Kebutuhan pasar masih dipasok dari hutan alam dengan menebang pohon untuk diambil kulitnya. Oleh karena itu perlu peningkatan pasokan melalui budidaya. Peningkatan produksi daun dapat dilakukan melalui pemangkasan dan pemupukan. Penelitian ini bertujuan untuk mengetahui efektivitas pemupukan terhadap pertumbuhan terubusan tanaman kilemo yang dipangkas. Pupuk organik tergranulasi buatan pabrik, pupuk daun mengandung unsur-unsur mikro, NPK (15:15:15) dan kontrol diberikan pada tanaman setelah satu bulan pemangkasan. Perlakuan diberikan dalam rancangan acak lengkap dengan jumlah unit perlakuan masing-masing 15 pohon diulang 3 kali. Untuk mengetahui respon pemupukan dilakukan penghitungan jumlah, panjang dan pendugaan total berat (produksi) terubusan terubusan pada hari ke-15, 30, 60, 90 dan 120 hari setelah pemangkasan. Hasil penelitian menunjukkan bahwa pupuk organik merupakan perlakuan yang paling efektif dalam meningkatkan jumlah, panjang dan total berat (produksi) terubusan. Pupuk organik $500 \mathrm{~g} / \mathrm{batang}$ dapat meningkatkan jumlah terubusan 116\%, panjang terubusan 99\% serta total berat (produksi) terubusan $475 \%$ dibanding kontrol. Perlakuan ini dapat meningkatkan ketersediaan N, P, K dan P total dalam tanah. Ketersediaan unsur-unsur hara tersebut berkaitan sangat erat dalam meningkatkan jumlah, panjang dan total berat (produksi) terubusan sampai tiga bulan setelah pemupukan.
\end{abstract}

Kata kunci: Kilemo, pemangkasan, pupuk organik, terubusan

\section{PENDAHULUAN}

Kilemo (Litsea cubeba L. Persoon) termasuk tumbuhan aromatis yang dapat didefinisikan sebagai tumbuhan yang memiliki aroma yang khas. Karena hampir semua bagian tumbuhan ini beraroma dan mengandung minyak atsiri (Kayang et al., 2009). Kilemo adalah sebutan jenis ini di daerah Jawa Barat, di Jawa Tengah disebut krangean dan di Sumatera Utara dinamai antarasa (Heyne, 1987). Tumbuhan ini termasuk famili Lauraceae, berupa perdu dengan diameter batang 
6-20 cm serta tinggi pohon 5-12 meter. Kilemo tersebar di Indonesia meliputi Pulau Jawa, Kalimantan dan Sumatera pada ketinggian 230-700 $\mathrm{m}$ di atas permukaan laut, terutama di daerah lereng gunung (Heyne, 1987).

Bagian tanaman yang paling banyak menghasilkan minyak atsiri adalah daun, kulit batang dan buah. Daun kilemo kering sempurna asal Sukabumi menghasilkan minyak atsiri sebanyak 7,9\%, penyulingan selama 8 jam dengan metode kukus menghasilkan rendemen minyak daun $(5,4 \%)$ lebih tinggi bila dibandingkan dengan rendemen dari kulit batang (1,6\%) (Zulnely et al., 2008). Kandungan minyak esensial pada daun, kulit batang dan biji telah banyak diteliti dan telah diindentifikasi unsur kimia penyusunnya, antara lain sineol, sitronelal, sitral, lemonal, sitronelol, dan lain-lain (Ho et al., 2010). Kilemo termasuk tumbuhan berkayu penghasil triasilgliserol (minyak), biji mengandung minyak hingga 49,1\% (Chen etal., 2008).

Secara empirik minyak kilemo telah dimanfaatkan sebagai obat tradisional seperti obat untuk mengatasi kejang urat atau otot, obat batuk, penghangat dan sebagai rempah rempah. Pada era modern ini minyak kilemo banyak dimanfaatkan terutama pada industri farmasi, wewangian, bahan tambahan makanan dan minuman, bahan sabun dan bahan pencampur vitamin yang larut dalam lemak misalnya vitamin A dan D. Minyak kilemo dimanfaatkan dalam industri makanan dan kosmetik (Widodo \& Widyastuti, 2012). Disamping sering digunakan dalam industri makanan dan makanan ternak, minyak tersebut juga dapat digunakan dalam industri kimia seperti cat, tinta, resin, vanish, plastik dan biodisel (Chen et al., 2008).

Informasi yang disampaikan oleh Nagpal \& Karki (2004) bahwa minyak kilemo termasuk 10 besar minyak esensial dalam perdagangan dunia, tetapi di Indonesia minyak tersebut belum begitu populer sehingga secara ekonomi masih belum diusahakan secara optimal. Indonesia termasuk salah satu negara penghasil minyak kilemo, namun dalam jumlah yang kecil. Selain itu, minyak yang dihasilkan umumnya berasal dari daun yang memiliki kandungan sitral yang rendah, sehingga kurang sesuai untuk tujuan ekspor. China adalah negara penghasil minyak kilemo yang besar (mencapai 1.500 ton per tahun), untuk memenuhi kebutuhan domestik dan diekspor ke luar negeri. Negara pengimpor minyak kilemo utama adalah Amerika Serikat, negara-negara Eropa Barat, dan Jepang (FAO, 1995).

Umumnya masyarakat memenuhi pasokan permintaan kilemo dari kulit batang yang diambil dari hutan alam. Hal ini mendorong terjadinya kepunahan tumbuhan kilemo karena untuk mengambil kulit batang harus dilakukan penebangan. Oleh karena itu perlu dilakukan upaya budidaya untuk menghindari dari kepunahan dan untuk memenuhi permintaan minyak kilemo. Merujuk pada hasil penelitian Zulnely et al. (2008) bahwa kandungan minyak daun lebih tinggi dibanding kulit batang, maka perlu dilakukan tindakan pemangkasan untuk memperbanyak produksi daun. Disamping itu dapat juga dilakukan pemupukan untuk meningkatkan ketersediaan unsur hara dalam tanah sehingga peningkatan produksi daun lebih optimal. Tujuan penelitian ini adalah untuk mengetahui efektivitas pemupukan terhadap peningkatan produksi daun pada tanaman kilemo yang dipangkas.

\section{METODOLOGI}

\section{A. Lokasi, waktu, bahan dan alat}

Penelitian dilakukan di Hutan Penelitian Cikole, Lembang Jawa Barat dari bulan Maret - Juli 2013. Alat-alat yang digunakan meliputi gergaji, tangga, timbangan, meteran dan tally sheet. Bahanbahan yang digunakan meliputi tanaman kilemo umur 2 tahun, pupuk NPK (15:15:15), pupuk organik tergranulasi, pupuk daun yang mengandung unsur-unsur mikro (Lampiran 1), kantong plastik serta kantong sampel. Analisis kimia tanah dilakukan di laboratorium Kimia dan Kesuburan tanah, Institut Pertanian Bogor.

\section{B. Metode}

\section{Perlakuan}

Perlakuan yang diberikan pada penelitian ini meliputi pemangkasan sebagai perlakuan dasar dan pemupukan. Penelitian ditujukan untuk mencari jenis pupuk yang paling tepat dan dosis pupuk yang digunakan sesuai dalam kemasan untuk tanaman perkebunan/kehutanan umur 2 tahun, yaitu NPK (200 gram/batang), pupuk organik pabrikan tergranulasi (500 gram/batang), pupuk daun yang mengandung unsur hara mikro ( 3 gram dilarutkan dalam 10 liter air) dan tanpa pupuk sebagai kontrol.

\section{Rancangan Penelitian}

Pemangkasan merupakan perlakuan dasar maka tidak dihitung sebagai faktor perlakuan (diabaikan), sehingga pemupukan merupakan faktor tunggal. Penelitian dilakukan dalam rancangan acak lengkap (RAL), dengan masing-masing perlakuan diberikan pada 15 batang tanaman dengan 3 kali 
ulangan, sehingga penelitian ini menggunakan 180 batang tanaman. Untuk analisis data, sampel diambil secara acak sebanyak 5 batang untuk tiap perlakuan sehingga data yang dianalisis sebanyak 4 perlakuan $\times 5$ batang $\times 3$ ulangan $=60$ batang.

\section{Prosedur kerja}

a. Pemangkasan

Pemangkasan dilakukan pada bagian batang di atas percabangan terbawah dengan menggunakan gergaji. Bagian batang yang terbuka setelah terpangkas ditutup menggunakan kantong plastik yang ditelungkupkan untuk menghindari penguapan berlebihan dan menghindari pembusukan akibat genangan air hujan.

b. Pemupukan

Pemupukan dilakukan setelah satu bulan pemangkasan. Hal ini dilakukan supaya kondisi tanaman stabil setelah mengalami gangguan. Sebelum dilakukan pemupukan kantong plastik penyungkup batang dibuka. Untuk aplikasi pupuk NPK dan pupuk organik, tanah di sekitar perakaran digali sedalam $5 \mathrm{~cm}$ dengan radius selebar tajuk kemudian pupuk ditaburkan dan tanah ditutup kembali. Adapun pupuk daun yang sudah dilarutkan disemprotkan merata pada bagian bawah dan atas permukaan daun supaya masuk ke dalam sistem tanaman melalui stomata.

c. Pengumpulan Data

1) Pengamatan pertumbuhan

Data yang diamati meliputi pertumbuhan terubusan tiap batang kilemo (jumlah, panjang dan perkiraan berat) terubusan yang dilakukan pada hari ke-15, 30, 60, 90 dan 120 setelah pemangkasan. Panjang terubusan diukur menggunakan meteran dihitung dari pangkal titik tumbuh sampai ujung tunas. Adapun perkiraan berat terubusan dihitung melalui pengambilan sampel untuk tiap perlakuan sebanyak 5 batang dan tiap batang diambil 3 cabang (15 terubusan/perlakuan) kemudian ditimbang dan dirata-rata beratnya untuk tiap $\mathrm{cm}$ terubusan. Setelah didapatkan angka ratarata berat per terubusan kemudian dikalikan dengan total jumlah terubusan.

2) Pengambilan sampel tanah

Sampel tanah diambil untuk mengetahui perubahan kondisi tanah sebelum, sesaat dan sesudah pemupukan pada interval waktu tertentu. Pengambilan sampel sebelum pemupukan dilakukan untuk mengetahui kondisi awal tanah. Pada penelitian ini pengambilan sampel tanah sebelum pemupukan dilakukan pada hari ke-15, sampel sesaat (waktu pemupukan) diambil pada hari ke-30, dan sesudah pemupukan dilakukan pengambilan sampel beberapa kali, yaitu 30 hari setelah pemupukan, 60 hari setelah pemupukan dan 90 hari setelah pemupukan (hari ke-60, ke-90 dan ke-120) setelah pangkas. Penghambilan sampel tanah dilakukan pada radius 1 sampai 1,5 meter dari batang pada kedalaman 0-20 cm. Selanjutnya sampel tanah dianalisis untuk mengetahui kandungan N, P dan K tanah.

\section{Analisis data}

Data dianalisis secara statistik menggunakan analisis varian dan apabila berbeda nyata dilanjutkan dengan analisis berganda dari Duncan. Korelasi antar variabel dihitung untuk mengetahui hubungan perubahan kesuburan tanah dengan pertumbuhan terubusan. Disamping itu untuk mengetahui efektivitas pemupukan akan dihitung efektivitas masing-masing perlakuan pemupukan dibandingkan dengan perlakuan yang tidak dipupuk (kontrol) dengan menggunakan rumus:

Efektivitas $=\frac{(\text { perlakuan }- \text { kontrol })}{\text { kontrol }} \times 100 \%$

2

\section{HASIL DAN PEMBAHASAN}

\section{A. Hasil}

Hasil analisis keragaman pengaruh perlakuan pemupukan terhadap panjang, jumlah dan total berat produksi terubusan disajikan pada Tabel 1. Hasil tersebut menunjukkan bahwa semua perlakuan pemupukan memberikan pengaruh terhadap panjang, jumlah dan produktivitas (total berat) terubusan kilemo satu, dua dan tiga bulan setelah pemupukan.

\section{Jumlah terubusan per batang}

Gambar 1 menunjukkan bahwa jumlah terubusan meningkat sampai dengan hari ke-90 setelah pemangkasan. Setelah tiga bulan sebagian terubusan akan mati, sehingga yang tersisa hanya beberapa buah. Pengaruh pemupukan terhadap jumlah terubusan menunjukkan bahwa waktu satu bulan setelah pemupukan (H-60) pupuk daun memberikan pengaruh paling baik dibandingkan dengan perlakuan pupuk lainnya terhadap jumlah terubusan rata-rata tiap batang. Antara perlakuan pupuk organik dan NPK menunjukkan pengaruh yang tidak berbeda nyata terhadap kontrol. Pada waktu dua bulan setelah pemupukan (H-90) ter- 
jadi perubahan respon, pupuk organik memberikan pengaruh paling signifikan dibandingkan kontrol diikuti oleh pupuk daun dan NPK yang tidak berbeda nyata terhadap kontrol. Pada waktu tiga bulan setelah pemupukan (H-120) menun- jukkan bahwa semua perlakuan pemupukan memberikan pengaruh yang berbeda nyata terhadap kontrol, tetapi tidak berbeda antar perlakuan (Gambar 1).

Tabel 1. Hasil Anova pengaruh perlakuan terhadap panjang, jumlah dan total weight (production) of shoota terubusan

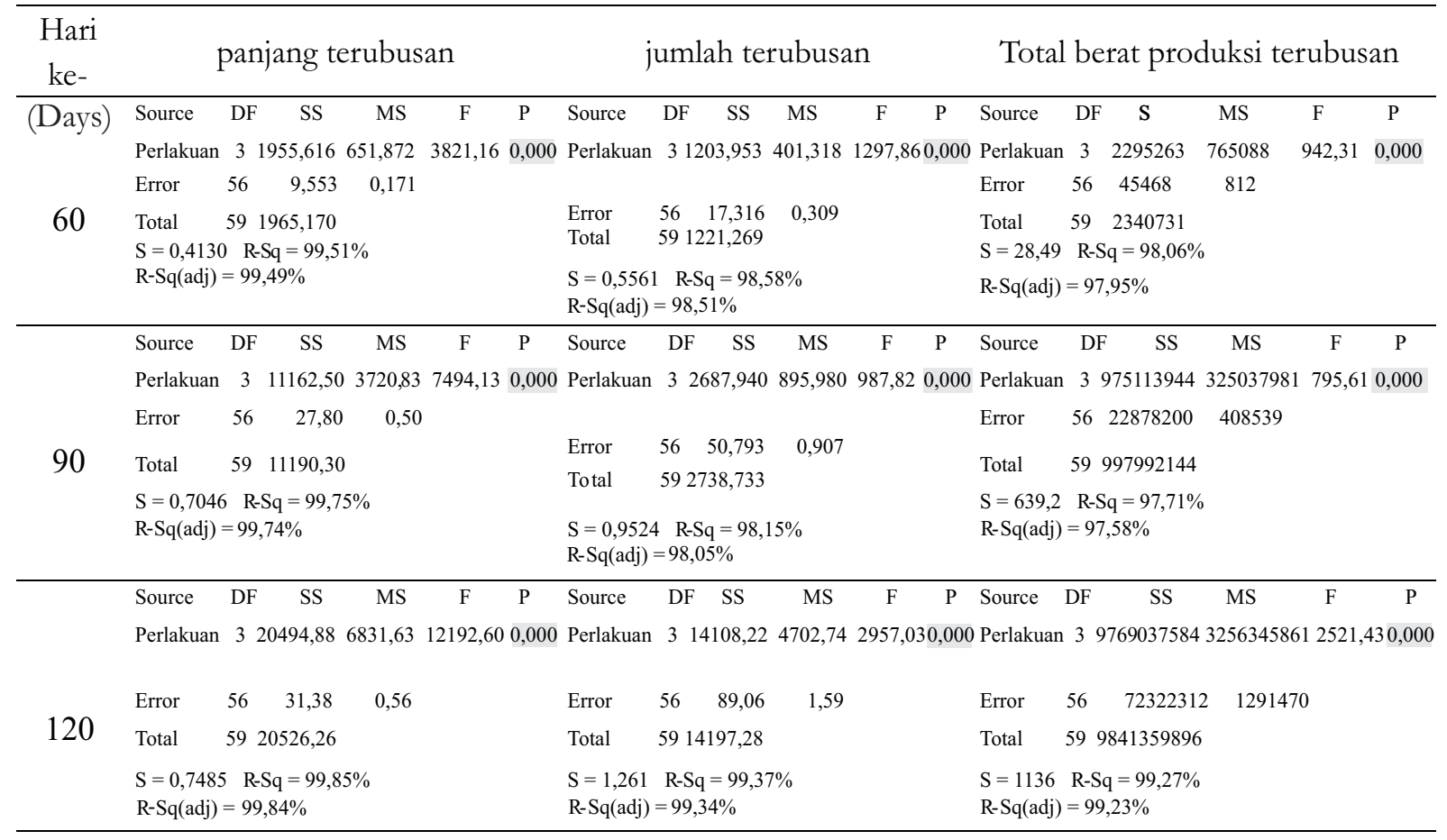

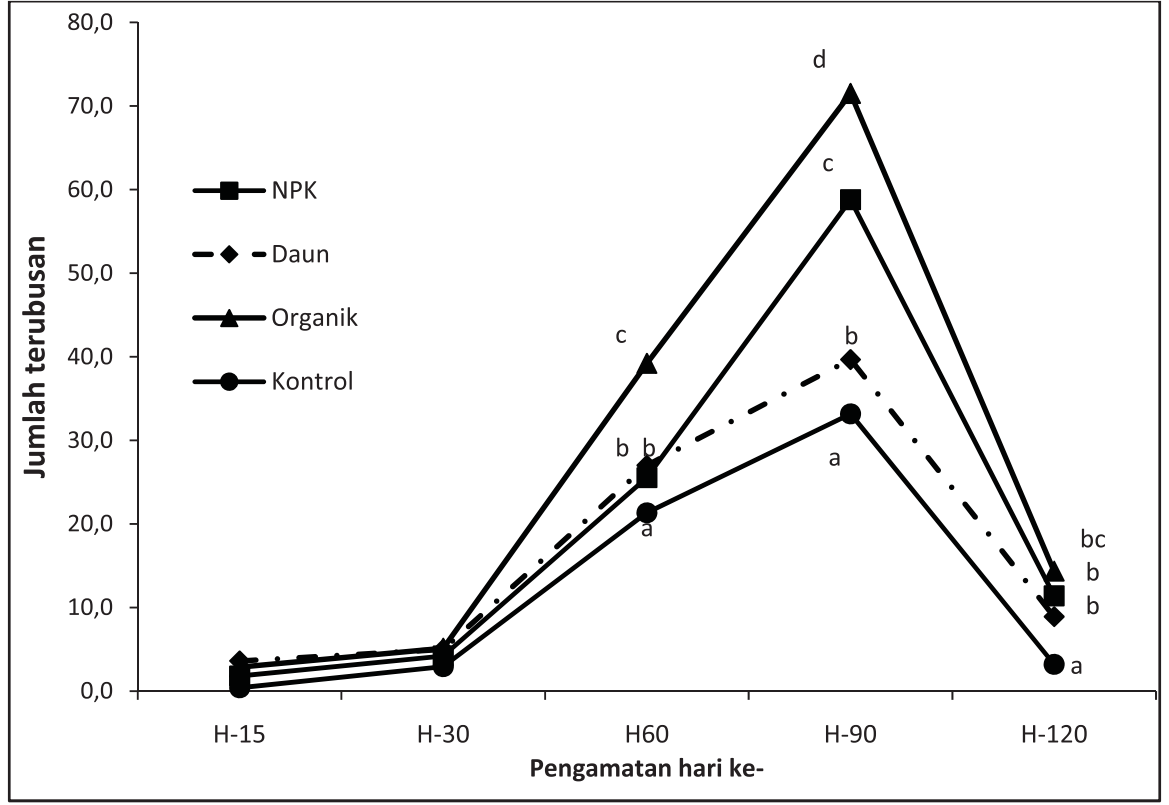

Keteranga: (huruf yang sama pada titik dalam grafik menunjukkan tidak berbeda nyata menurut hasil uji Duncan)

Gambar(Figure) 1. Pengaruh pemupukan terhadap jumlah terubusan kilemo (impacts of fertilizer on kilemo coppies number) 


\section{Panjang tiap terubusan}

Gambar 2 menunjukkan bahwa pada waktu pengamatan satu, dua dan tiga bulan setelah pemupukan penambahan pupuk memberikan pengaruh yang signifikan terhadap pertumbuhan panjang terubusan kilemo dibandingkan dengan kontrol yang tidak diberi pupuk. Setelah satu bulan dipupuk (H-60) pupuk organik dan pupuk daun memberikan pengaruh yang paling signifikan dibanding kontrol dan NPK, tetapi diantara pupuk daun dan pupuk organik tersebut tidak berbeda nyata. Pada pengamatan setelah dipupuk dua bulan (H-90) dan tiga bulan (H-120) pupuk organik memberikan pengaruh yang paling nyata, diikuti oleh pupuk NPK dan pupuk daun yang diantara keduanya tidak berbeda nyata tetapi berbeda secara signifikan dibanding kontrol.

\section{Total berat produksi terubusan per Batang}

Perlakuan pemupukan menunjukkan perbedaan yang nyata terhadap perkiraan total berat produksi terubusan pada hari ke-90 pengamatan (dua bulan setelah pemupukan) dibandingkan dengan tanaman yang tidak dipupuk (Gambar 3). Pada hari ke-120 berat terubusan mengalami penurunan. Pada penelitian ini pupuk organik, merupa- kan perlakuan yang paling signifikan dalam meningkatkan berat terubusan kilemo pada dua dan tiga bulan setelah dipupuk, diikuti oleh pupuk NPK.

\section{Efektivitas pemupukan terhadap pertum- buhan terubusan}

Tabel 2 menunjukkan bahwa pada akhir pengamatan pupuk organik merupakan perlakuan yang paling efektif dalam meningkatkan jumlah, panjang dan total berat (produksi) terubusan terubusan kilemo yang dipangkas. Perlakuan ini melipatkan jumlah terubusan lebih dari dua kali, panjang terubusan dua kali dan total berat (produksi) terubusan hampir lima kali lipat dibanding kontrol.

Tabel 3 menunjukkan bahwa perlakuan pemupukan dapat meningkatkan kandungan N, P total, $\mathrm{P}$ tersedia dan $\mathrm{K}$ tanah mulai pada saat pupuk ditambahkan (H-30). Peningkatan ketersediaan keempat variabel kesuburan tersebut yang paling signifikan diberikan oleh perlakuan pupuk organik dan pupuk NPK. Antara pupuk NPK dan pupuk organik tidak memberikan hasil yang berbeda nyata.

Tabel 4 menunjukkan bahwa hubungan antara

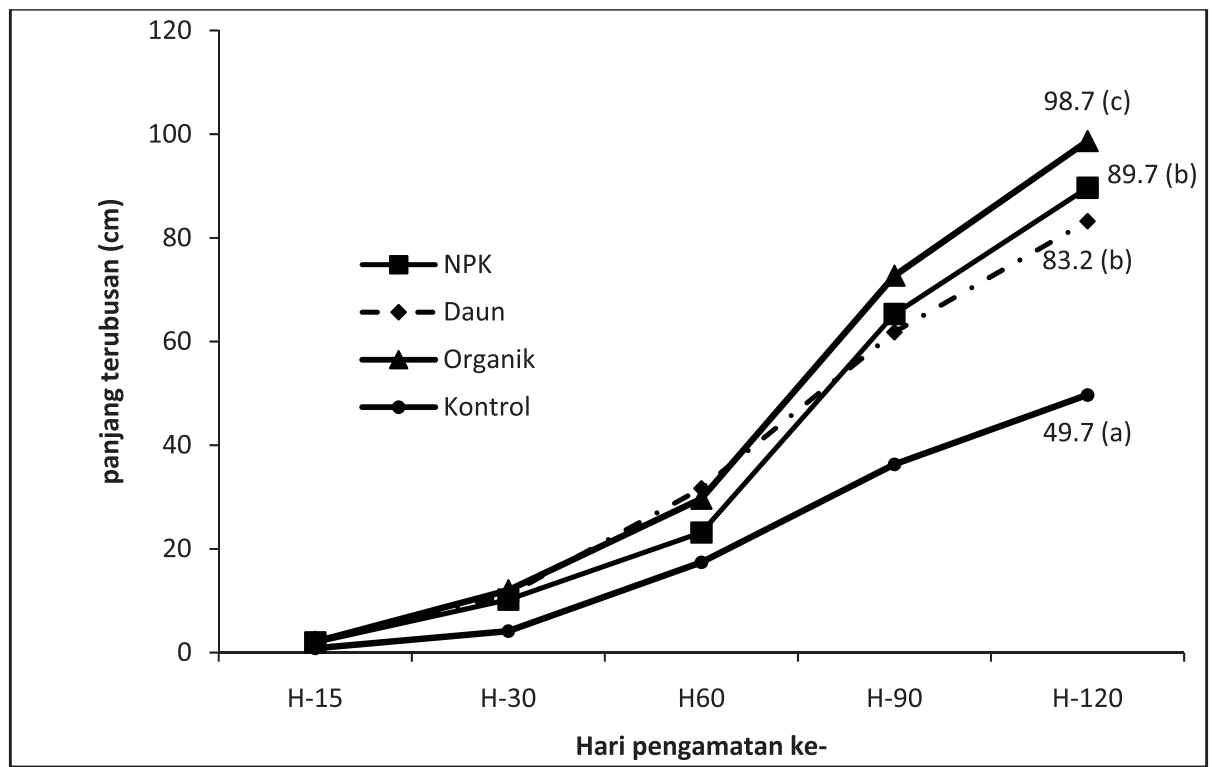

Gambar(Figure)2. Pengaruh pemupukan terhadap panjang terubusan kilemo (Impacts of fertilizer on kilemo coppies lenght) 


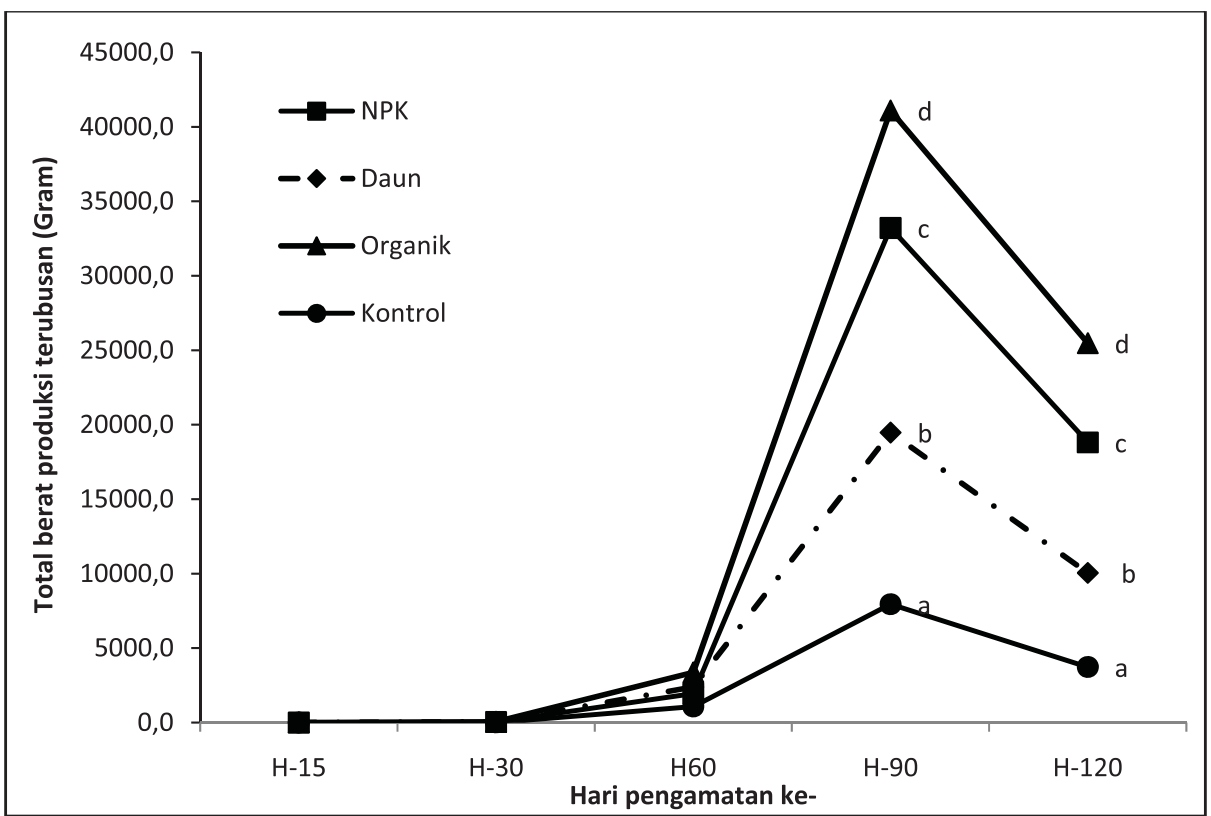

Gambar(Figure) 3. Total total berat produksi terubusan tiap batang (Weight total of coppies production of each tree)

Tabel(Table) 2. Efektivitas perlakuan pemupukan terhadap pertumbuhan terubusan (Effectiveness of fertilizers on shoots growth) $(\%)$

\begin{tabular}{|c|c|c|c|c|c|c|c|c|c|c|c|c|}
\hline \multirow[b]{2}{*}{$\begin{array}{l}\text { Perlakuan } \\
\text { (treatments) }\end{array}$} & \multicolumn{4}{|c|}{$\begin{array}{l}\text { Jumlah terubusan } \\
\text { (number of shoots ) }\end{array}$} & \multicolumn{4}{|c|}{$\begin{array}{l}\text { Panjang terubusan } \\
\text { (of coppies) }\end{array}$} & \multicolumn{4}{|c|}{$\begin{array}{l}\text { Total berat produksi terubusan } \\
\text { (weight total of coppies) }\end{array}$} \\
\hline & H-30 & H-60 & H-90 & $\mathrm{H}-120$ & H-30 & H-60 & H-90 & H-120 & $\mathrm{H}-30$ & H- 60 & H-90 & H-120 \\
\hline NPK & 43 & 14 & 20 & 77 & 147 & 33 & 80 & 80 & 458 & 155 & 39 & 251 \\
\hline $\begin{array}{l}\text { Daun } \\
\text { (Leaffertilizer) }\end{array}$ & 71 & 115 & 27 & 20 & 33 & 82 & 70 & 67 & 900 & 247 & 259 & 188 \\
\hline $\begin{array}{l}\text { Organik } \\
\text { (Organic fert.) }\end{array}$ & 75 & 43 & 84 & 116 & 71 & 100 & 100 & 99 & 692 & 235 & 147 & 475 \\
\hline
\end{tabular}

peningkatan ketersediaan unsur hara dalam tanah berhubungan sangat erat dengan pertumbuhan panjang, jumlah dan peningkatan total berat (produksi) terubusan kilemo yang dipang-kas. Semua unsur hara yang diukur menunjukkan korelasi yang positif seperti yang disajikan pada Tabel 4. Penambahan pupuk organik dan NPK da-pat meningkatkan ketersediaan unsur hara dalam tanah. Adapun pupuk daun berkorelasi sangat kecil terhadap peningkatan unsur hara $(\mathrm{N}, \mathrm{P}$ tersedia, Ptotal dan K) dalam tanah karena pupuk tidak di tambahkan ke dalam tanah tetapi langsung diserap oleh stomata daun.

\section{PEMBAHASAN}


Tabel (Table) 3. Hasil analisis kimia tanah rhizosfir (chemical analysis of rhizosphere)

\begin{tabular}{|c|c|c|c|c|c|}
\hline \multirow{2}{*}{\multicolumn{2}{|c|}{$\begin{array}{l}\text { Kandungan hara } \\
\text { (Element contents) }\end{array}$}} & \multicolumn{4}{|c|}{ Perlakuan Pupuk (Fertilizer treatments) } \\
\hline & & Organik & Daun & NPK & Kontrol \\
\hline \multirow{5}{*}{$\begin{array}{c}\mathrm{N} \text { total } \\
(\%)\end{array}$} & H-15 & 0,60 & 0,58 & 0,60 & 0,62 \\
\hline & $\mathrm{H}-30$ & 0,61 & 0,55 & 0,83 & 0,63 \\
\hline & H-60 & 0,85 & 0,45 & 0,75 & 0,59 \\
\hline & $\mathrm{H}-90$ & 0,80 & 0,49 & 0,67 & 0,53 \\
\hline & H-120 & 0.78 & 0,48 & 0,70 & 0,58 \\
\hline \multirow{5}{*}{$\begin{array}{l}\text { P total } \\
\text { (ppm) }\end{array}$} & H-15 & 282 & 287 & 231 & 280 \\
\hline & $\mathrm{H}-30$ & 350 & 342 & 328 & 346 \\
\hline & H-60 & 426 & 352 & 430 & 313 \\
\hline & H-90 & 533 & 342 & 425 & 308 \\
\hline & $\mathrm{H}-120$ & 448 & 374 & 389 & 310 \\
\hline \multirow{5}{*}{$\begin{array}{c}\text { P tersedia } \\
(\mathrm{ppm})\end{array}$} & $\mathrm{H}-15$ & 1,88 & 1,66 & 2,02 & 1,85 \\
\hline & $\mathrm{H}-30$ & 2,45 & 1,64 & 3,86 & 1,92 \\
\hline & H-60 & 4,88 & 1,94 & 5,16 & 1,10 \\
\hline & $\mathrm{H}-90$ & 4,60 & 1,42 & 4,22 & 1,12 \\
\hline & $\mathrm{H}-120$ & 5,20 & 2,64 & 4,44 & 1,78 \\
\hline \multirow{5}{*}{$\begin{array}{c}\mathrm{K} \\
(\mathrm{Me} / 100 \mathrm{~g} \\
\operatorname{tanah})\end{array}$} & $\mathrm{H}-15$ & 0,42 & 0,47 & 0,60 & 0,57 \\
\hline & H-30 & 0,87 & 0,89 & 1,08 & 0,62 \\
\hline & H-60 & 0,60 & 0,52 & 1,61 & 0,57 \\
\hline & H-90 & 0,63 & 0,49 & 1,60 & 0,32 \\
\hline & H-120 & 1,21 & 0,98 & 1,12 & 0,43 \\
\hline
\end{tabular}

Tabel(Table) 4. Korelasi antara kandungan N, P total, P tersedia dan $\mathrm{K}$ tanah terhadap pertumbuhan jumlah, panjang dan total berat (produksi) terubusan (Correlation among soil content of $N$, P total, P available and K to the number, elongation, and total weight of coppies)

\begin{tabular}{|c|c|c|c|c|c|}
\hline Korelasi & $\begin{array}{l}\text { Jenis pupuk } \\
\text { (fertilizers) }\end{array}$ & $\mathrm{N}$ & P tersedia & P total & $\mathrm{K}$ \\
\hline \multirow{3}{*}{$\begin{array}{l}\text { Jumlah } \\
\text { Terubusan } \\
\text { (number of coppies) }\end{array}$} & Organik & 0,84 & 0,57 & 0,86 & 0,22 \\
\hline & NPK & 0,64 & 0,65 & 0,71 & 0,79 \\
\hline & Daun & 0,08 & 0,01 & 0,32 & 0,28 \\
\hline \multirow{3}{*}{$\begin{array}{l}\text { Panjang } \\
\text { Terubusan } \\
\text { (Elongation of } \\
\text { coppies) }\end{array}$} & Organik & 0,72 & 0,83 & 0,80 & 0,67 \\
\hline & NPK & 0,69 & 0,59 & 0,72 & 0,40 \\
\hline & Daun & 0,12 & 0,18 & 0,27 & 0,36 \\
\hline \multirow{3}{*}{$\begin{array}{l}\text { Total berat } \\
\text { produksi (Weight } \\
\text { total of coppies) }\end{array}$} & Organik & 0,47 & 0,64 & 0,50 & 0,80 \\
\hline & NPK & 0,43 & 0,79 & 0,32 & 0,53 \\
\hline & Daun & 0,13 & 0,27 & 0,35 & 0,27 \\
\hline
\end{tabular}




\section{B. Pembahasan}

Pemangkasan tanaman pada tanaman kehutanan umumnya bertujuan untuk membuang cabangcabang tidak produktif, membentuk pertumbuhan pohon dan merangsang tumbuhnya tunas-tunas baru. Pada penelitian ini pohon kilemo dipangkas ditujukan untuk membentuk tunas-tunas baru sehingga dapat menghasilkan lebih banyak daun yang akan dipanen untuk disuling minyaknya. Pohon kilemo cenderung membentuk tajuk berbentuk kerucut, cabang-cabang sebelah bawah segera mati, akibatnya makin tinggi umur pohon makin tinggi letak daun (Gambar 4 kiri) sehingga menyulitkan pemanenannya.

Langkanya cabang-cabang tanaman kilemo pada batang bagian bawah diduga karena adanya mekanisme dominansi apikal (apical dominance). Dominansi apikal adalah pertumbuhan ujung pucuk suatu tumbuhan yang menghambat perkembangan tunas-tunas lateral pada bagian batang sebelah bawah (Cline, 1997). Mekanisme dominansi apikal terjadi melalui pendifusian auksin oleh tunas pucuk ke bawah, akibatnya konsentrasi auksin pada batang bagian bawah menjadi terlalu tinggi sehingga menghambat pertumbuhan tunas lateral. Auksin merupakan salah satu hormon pertumbuhan, dimana hormon merupakan suatu senyawa yang apabila berada dalam konsentrasi yang rendah sampai cukup (adequate) akan memacu pertumbuhan tetapi ketika berada pada konsentrasi yang terlalu tinggi akan menghambat pertumbuhan (Wikipedia, 2013). Sehingga dapat difahami ketika konsentrasi auksin tinggi maka pertumbuhan tu-nas lateral akan terhambat.

Pemangkasan yang diterapkan pada penelitian ini menggunakan teknik coppice dengan menghilangkan $60-70 \%$ bagian pucuk. Hal ini diduga dapat memangkas dominansi apikal pada tanaman kilemo. Pemangkasan bagian pucuk ini diharapkan dapat menghambat aliran auksin ke bagian bawah sehingga tunas-tunas lateral tidak terhambat pertumbuhannya (Gambar 4). Cline (1997) menggambarkan mekanisme tumbuhnya terubusan ketika bagian pucuk dihilangkan. Ketika pucuk masih ada terjadi dominansi apikal yang menghambat tumbuhnya tunas lateral karena dihambat oleh meristem tunas pucuk (shoot apical meristem $=\mathrm{SAM}$ ). Hal ini disebabkan oleh letak calon tunas lateral berada di bawah SAM. SAM selalu mengeluarkan auksin pada konsentrasi yang dapat menghambat pertumbuhan tunas lateral tersebut. Ketika pucuk dipangkas hilanglah SAM sehingga tunas lateral dapat tumbuh dan berkembang membentuk cabang-cabang baru.
Pada penelitian ini terdapat dinamika pertumbuhan terubusan, yaitu terjadi kematian terubusan yang signifikan pada tiga bulan setelah pangkas yang ditunjukkan dengan menurunnya jumlah terubusan (Gambar 1) sehingga dapat menurunkan total berat produksi terubusan (Gambar 3). Kematian terubusan tersebut diduga terjadi akibat adanya pengaturan hormon oleh tanaman untuk membatasi jumlah tunas yang dapat berkembang. Menurut Dun et al., (2006) peranan dan pengaturan hormon-hormon pertumbuhan dalam mengatur tumbuhnya terubusan berlangsung dalam empat tahap. Pertama, begitu pucuk dihilangkan tanaman akan mengeluarkan sitokinin yang berperan dalam pembelahan sel sehingga tunas samping mengalami pemanjangan. Selanjutnya tanaman kembali mengeluarkan auksin untuk memfasilitasi terjadinya dominansi apikal, hal ini bertujuan untuk membatasi jumlah tunas samping (dominansi apikal) yang tumbuh sehingga tunas yang sudah terbentuk tumbuh optimal. Tahap ketiga tanaman mengeluarkan kembali hormon sitokinin yang mengatur pembelahan sel menghasilkan pertumbuhan menjadi lebih besar (outward) dan tahap terakhir tanaman membatasi produksi auksin dan mengeluarkan giberelin yang juga berfungsi untuk pembelahan sel. Akhirnya tunas lateral makin berkembang (outgrow) membentuk cabang-cabang baru. Dinamika tersebut dapat dijadikan sebagai salah satu pertimbangan dalam melakukan pemanenan kilemo. Apabila akan memanen daun maka lebih baik dilakukan maksimal 3 bulan setelah pemangkasan, sedangkan untuk memanen kulit dapat dilakukan pada periode lebih panjang.

Untuk meningkatkan hasil panenan, telah dilakukan pemupukan dengan tiga jenis pupuk. Hasil pengamatan pemupukan terhadap jumlah (Gambar 1), panjang (Gambar 2) dan berat (Gambar 3) terubusan menunjukkan bahwa pemupukan dapat meningkatkan ketiga variabel tersebut. Pada penelitian ini terdapat dinamika respon pemupukan terhadap pertumbuhan terubusan. Pada waktu awal setelah pemupukan yang memberikan respon lebih baik adalah pupuk-pupuk yang cepat tersedia, yaitu NPK dan pupuk daun. Pupuk daun dan NPK baik untuk memacu tanaman menghasilkan jumlah (Gambar 1) dan panjang (Gambar 2) terubusan lebih banyak sampai pada hari ke-60. Hal ini karena pupuk inorganik segera dapat digunakan oleh tanaman. Sedangkan pupuk organik memerlukan waktu untuk dapat tersedia karena memerlukan air dan bantuan mikrob tanah untuk menguraikannya menjadi unsur-unsur hara yang bisa diserap oleh tanaman. 
Namun setelah pupuk organik tersedia bagi tanaman maka pupuk tersebut yang memberikan pengaruh paling signifikan terhadap jumlah (Gambar 1), panjang (gambar 2) dan produksi (berat) terubusan sampai hari ke-120 setelah pemangkasan.

Pupuk organik yang dipergunakan pada penelitian ini merupakan buatan pabrik yang dikendalikan mutunya sehingga tidak berubah-ubah kandungan nutrisi dan bahan lainnya. Menurut Subba Rao (1982) pupuk organik buatan, yaitu pupuk organik yang diproduksi di pabrik dengan menggunakan peralatan yang modern. Hasil penelitian juga menunjukkan pupuk organik secara signifikan meningkatkan status kesuburan tanah, yaitu meningkatkan N, P total, P tersedia dan K dalam rhizosfir tanaman (Tabel 4). Pupuk organik dapat memberikan pengaruh yang paling nyata karena pupuk tersebut selain mengandung bahan organik juga mengandung berbagai mikrob penambat N, P dan K serta mikrob penghasil hormon-hormon pertumbuhan (Tabel Lampiran 1). Merujuk pada Dun et al. (2006) tersebut di atas dimana tumbuhnya terubusan sangat dipengaruhi oleh hormon pertumbuhan maka penambahan pupuk organik yang mengandung mikrob penghasil hormon pengatur tumbuh dapat meningkatkan produktivitas terubusan yang paling baik dibandingkan pupuk NPK dan pupuk daun (Gambar 3).

Perlakuan terbaik kedua diberikan oleh pupuk
NPK yang memberikan hasil tidak berbeda nyata dengan pupuk organik (kecuali pada variabel berat produksi terubusan) karena NPK merupakan pupuk inorganik yang cepat dapat dimanfaatkan oleh tanaman (fast released fertilizer). Pupuk daun memberikan hasil yang paling rendah tetapi masih lebih baik dibanding kontrol. Hal ini karena daun yang disemprot jumlahnya masih sangat terbatas sehingga pupuk yang diberikan hanya sedikit yang bisa diambil oleh tanaman.

Hasil penelitian ini sejalan dengan perlakuan pemangkasan pada tanaman teh untuk meningkatkan produktivitas pucuk yang dilakukan oleh Effendi et al. (2010). Hasil penelitian Effendi et al. (2010), tingkat kesuburan tanah mempengaruhi kecepatan dan tingkat produksi pucuk teh. Makin subur tanah suatu kebun, makin cepat pertumbuhan tanaman yang berarti makin pendek daur pangkasannya, bila dibandingkan dengan tanaman pada tanah yang kurang subur. Menurut Marsono \& Sigit (2002) pemberian pupuk NPK sangat berperan dalam mendukung pertumbuhan panjang tunas teh, sebab pupuk NPK di dalamnya terdapat unsur nitrogen $(\mathrm{N})$ yang sangat berperan dalam pertumbuhan vegetatif tanaman. Secara umum pemberian pupuk NPK akan meningkatkan pertumbuhan vegetatif, perkembangan sistem perakaran dan ketahanan terhadap serangan hama atau penyakit (Mashudi et al., 2008) sehingga meningkatkan produktivitas pucuk daun teh.

Perlakuan pemupukan meningkatkan
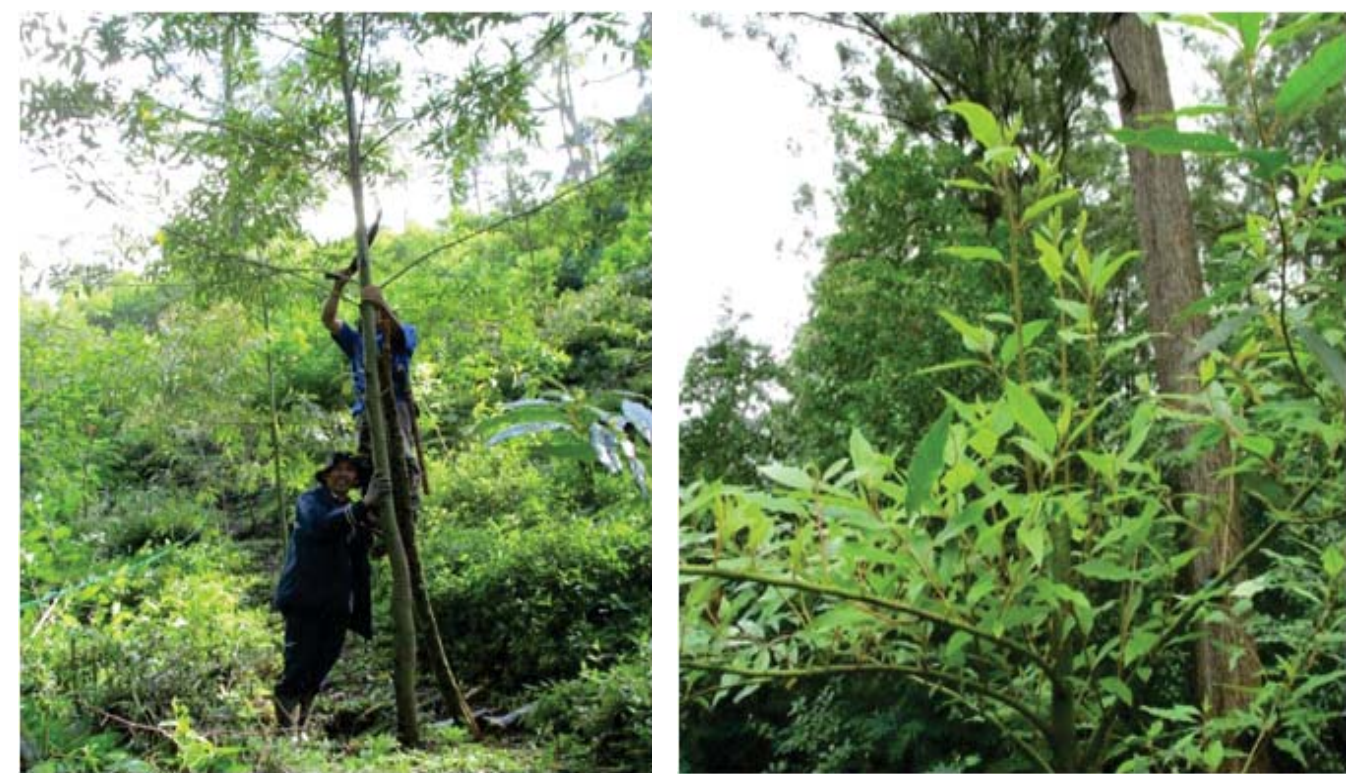

Gambar(figure) 4. Keragaan kilemo tidak menghasilkan tunas lateral (kiri) pemangkasan memacu tumbuhnya tunas lateral (kanan) (Kilemo performance with lack of lateral buds (left), prunning encourage lateral buds development (right)) 
kandungan $\mathrm{N}, \mathrm{P}$ tersedia, $\mathrm{P}$ total dan $\mathrm{K}$ tanah (Tabel 4), dan tumbuhnya terubusan sangat dipengaruhi oleh sta-tus hara dalam tanah yang ditunjukkan oleh hasil analisis korelasi positif (Tabel 5). Tanah selalu kekurangan $\mathrm{N}$ tersedia karena unsur tersebut sangat mudah tercuci, mudah menguap dan mudah diimobilisasi oleh mikrob. Tanah juga selalu kekurangan $\mathrm{P}$ karena jumlah $P$ yang dapat diserap oleh tanaman sangat sedikit yaitu $\pm 20 \%$ dari yang diberikan karena diimmobilisasi oleh mikrob, terjerap dalam koloid tanah atau tercuci (Soepardi, 1983). Pupuk organik merupakan perlakuan yang paling signifikan karena mengandung mikrob penambat nitrogen serta mikrob yang membantu melepaskan P dan K dari jerapan koloid (Tabel lampiran 1).

Meningkatnya produksi pucuk hasil penelitian ini karena meningkatnya unsur $\mathrm{N}$ yang selain ber-peran membantu pertumbuhan vegetatif tanam-an juga merupakan unsur utama penyusun klorofil (Soepardi, 1983). Unsur P berperan dalam perkem-bangan akar (Soepardi, 1983) serta penting dalam proses pemecahan karbohidrat untuk dijadikan ener-gi, penyimpanan dan peredarannya ke seluruh tanaman dalam bentuk ADP dan ATP, juga berperan dalam pembelahan sel melalui peranan nukleopro-tein yang ada dalam inti sel (Leiwakabessy, 2004). Adapun peranan utama kalium bagi tanaman ada-lah sebagai aktivator berbagai enzim, merangsang pertumbuhan akar dan sebagai unsur esensial dalam pembentuk dan pengisian klorofil (Soepardi, 1983) serta terutama berfungsi dalam proses fotosinte-sis, pengangkutan hasil asimilasi, aktivasi enzim, dan pengangkutan mineral termasuk air (Leiwakabessy, 2004). Oleh karena itu meningkatnya ketiga unsur hara tersebut dalam tanah akibat pemupu-kan dapat meningkatnya pertumbuhan terubusan kilemo.

\section{KESIMPULAN}

Pupuk organik tergranulasi dengan dosis 500 gram/pohon merupakan perlakuan yang paling efektif dalam meningkatkan jumlah, panjang dan total berat (produksi) terubusan terubusan kilemo umur 2 tahun yang dipangkas. Perlakuan ini dapat meningkatkan jumlah terubusan $116 \%$, panjang terubusan $99 \%$ serta total berat (produksi) terubusan $475 \%$. Hal ini karena pupuk organik meningkatkan ketersediaan $\mathrm{N}, \mathrm{P}$ dan $\mathrm{K}$ serta $\mathrm{P}$ total dalam tanah. Ketersediaan unsur-unsur hara

\section{DAFTAR PUSTAKA}

Chen, Y.,Wang Y. Zhou, G. Li, P. Zhang, S. (2008). Key mediators modulating TAG synthesis and accumulation in woody oil plants. Afr. $J$. Biotechnol. 7(25): 4743-4749.

Cline, M. (1997). The role of hormones in apical dominance. New approaches to an old problem in plant development. Physiologia Plantarum 90: 230-237.

Dun, E. A.,ferguson B.J. Beveridge, C.A. (2006). Api-cal dominance and shoot branching. Divergent opinions or divergent mechanisms? Plant Physiology 142 (3): 812-819. doi:10. 1104/pp.106.086868. PMC 1630731. PMID 17093134.

Effendi, D.S., Syakir, M. Yusron, Wiratno. (2010). Budidaya dan pasca panen teh. Pusat Penelitian dan Pengembangan Perkebunan. Bogor.

Food and Agricultural Organization (FAO). (1995). Fla-vours and Fragances of Plant Origin. Viale dells Terme di Caracalla, 00100 Rome, Italy.

Heyne, K. (1987). Tumbuhan Berguna Indonesia Jilid II Cetakan ke-1. Badan Penelitian dan Pengembangan Kehutanan. Departemen Kehutanan. Jakarta.

Ho, CL., Qu, JP. Liu, YC. Hung, CP. Tsai, MC. Liao, P.C. Wang, EIC. Chen, YL. Su, YC. (2010). Compositions and in vitro anticancer activities of the leaf and fruits oils of Litsea cubeba from Taiwan. Natural Product Communications, 5: 617-620.

Kayang, H.,Kharbuli B. Syeim, D. (2009). Litsea cubeba Pers.An untapped economic plant species of Meghalaya. Natural Product Radiance, A Bimontly Journal on Natural Product, 8(1): 1-2.

Leiwakabessy, F. M. (2004). Pupuk dan pemupukan. Jurusan Tanah. FakultasPertanian. Institut Pertanian Bogor. 207 hal.

Marsono \& P. Sigit. (2002). Pupuk akar : Jenis dan aplikasinya. PT. Penebar Swadaya. Jakarta.

Mashudi, Adinugraha, H.A. Setiadi, D. Ariani, F. (2008). Pertumbuhan tunas tanaman pulai pada beberapa tinggi pangkasan dan dosis pupuk NPK. Jurnal Pemuliaan Tanaman Hutan. Vol. 2 No. 2, September 2008: 1 - 9 . 
Nagpal, A. \& Karki M. (2004). A Study on marketing oppottunities for medicinal, aromatic, and dye plants in South Asia. MAPPA, ICIMOD, Kathmandu, Nepal. p: 35 .

Subba Rao, N.S. (1982). Biofertilizer in agriculture. Oxford and IBH Publishing Co., New Delhi.

Soepardi, G. 1983. Sifat dan ciri-ciri tanah. Jurusan Tanah. Fakultas Pertanian. Institut Pertanian Bogor. 591 hal.

Widodo, H. \& Widiyastuti Y. (2012). Kilemo (Litsea cubeba (Lour.) Persoon): Aspek agronomi, penggunaan secara tradisional, bioaktivitas dan potensinya. Akses tanggal 24 Novenber 2013, dari: http://herbalnet.healthrepository.org/bitstream/123456789/2633/2/L N-1.Kilemo Litsea cubeba L. Per-soon.pdf (diakses 24 Nopember 2013).

Wikipedia. (2013). Auxine, cytocinine, gybereline. Akses tanggal 12 Oktober 2013, dari: www.wikipediathefreeencyklopedia.com.

Zulnely, Kulsum U. Junaedi, A. (2008). Sifat fisiko kimia minyak kilemo (Litsea cubeba) asal Kuningan, jawa barat. Akses tanggal 24 November, dari: htt p : / / ford a mof.org/files/1022\%20 kilemoZULNELLY.pdf. 
Tabel Lampiran (Appendix) 1. Kandungan unsur hara dan mikrob pupuk yang diaplikasikan (nutrients and microbes content of the fertilizers) (disarikan dari kemasan/summarized from the labels)

\begin{tabular}{lll}
\hline \multicolumn{1}{c}{ Jenis Pupuk } & \multicolumn{1}{c}{ Kandungan unsur hara } & Kadar \\
\hline Pupuk daun & Mangan (Mn) & $70 \mathrm{~g} / \mathrm{kg}$ \\
(leaffertilizer & Besi (Fe) & $25 \mathrm{~g} / \mathrm{kg}$ \\
& Tembaga (Cu) & $20 \mathrm{~g} / \mathrm{kg}$ \\
& Molibdenum (Mo) & $1 \mathrm{~g} / \mathrm{kg}$ \\
& Zinc (Zn) & $50 \mathrm{~g} / \mathrm{kg}$ \\
& Boron (Bo) & $20 \mathrm{~g} / \mathrm{kg}$ \\
\hline Pupuk Organik & Karbon organik (Corg) & $>12 \%$ \\
(organic fertilizer & C/N & $10-25$ \\
& Kadar air (water content) & $<20 \%$ \\
& pH & $6-8$ \\
\hline NPK & Mikrob penambat N, pelarut P\&K serta penghasil ZPT & $10^{4}-10^{6} \mathrm{spk} / \mathrm{g}$ \\
\hline & Nitrogen (N) & $15 \%$ \\
& Fosfor (P) & $15 \%$ \\
& Kalium (K) & $15 \%$ \\
\hline
\end{tabular}

Tabel Lampiran (appendix) 2. Hasil rata-rata penimbangan contoh terubusan (measurement of samples of coppies weightsaverage $(\mathrm{gram} / \mathrm{cm})$

\begin{tabular}{|c|c|c|c|c|c|c|c|c|c|}
\hline $\begin{array}{c}\text { Perlakuan } \\
\text { (treatments) }\end{array}$ & $\begin{array}{l}\mathrm{H}-15 \\
\text { (days 15) }\end{array}$ & & $\begin{array}{l}\mathrm{H}-30 \\
\text { days 30) }\end{array}$ & & $\begin{array}{l}\mathrm{H}-60 \\
\text { days } 60 \text { ) }\end{array}$ & & $\begin{array}{l}-90 \\
y s 90)\end{array}$ & \multicolumn{2}{|c|}{$\begin{array}{c}\mathrm{H}-120 \\
(\text { days 120) }\end{array}$} \\
\hline NPK & 1.0 (a) & 1.2 & (a) & 3.0 & (a) & 4.9 & (c) & 6.2 & (b) \\
\hline Daun & 1.0 (a) & 1.1 & (a) & 2.8 & (a) & 4.1 & (b) & 5.9 & (b) \\
\hline Organik & 1.0 (a) & 1.2 & (a) & 2.9 & (a) & 4.9 & (c) & 6.3 & (b) \\
\hline Kontrol & 1.0 (a) & 1.1 & (a) & 2.8 & (a) & 3.1 & (a) & 5.0 & (a) \\
\hline
\end{tabular}

